\title{
Differences in Stress Resistances of Rooted Sweet Potato Leaves ${ }^{1}$
}

\author{
Franklin W. Martin ${ }^{2}$
}

ABSTRACT

Rooted leaves from 15 sweet potato cultivars or lines were grown in small pots in four environments, greenhouse plus three environments which were considered stressful: full sun in small pots, partial shade, and flooding of roots. The effects of the three stress environments were observed in eight characteristics. Each stress situation reduced storage root production and produced characteristic responses. Cultivars differed in their response to each stress. Some cultivars, especially "Gem" and "Jaspar," were more productive and less influenced by stress than all others.

\section{INTRODUCTION}

Young sweet potato leaves removed from the plant can be rooted. Rooted leaves may enlarge, store nutrients in the petiole, form storage roots and regenerate new plants. ${ }^{3}$ Rooted leaves in pots have been shown to be suitable for physiological experiments because of their small size and mobility. ${ }^{4}$ In addition, they might be useful in screening for insect and disease resistance, and for stress tolerance. A standard technique for rooting leaves has been established. ${ }^{5}$

Differences among cultivars facilitate the production of a given crop in a wider range of environments than those suitable to any individual cultivar. Differences related to adaptation and especially to response to physiological stress conditions are desired because of the growing need to utilize marginal soils for food production. However, testing for adaptations is a laborious, time-consuming activity. In the case of the sweet potato, the use of a small modified plant that completes growth in 10 weeks, the rooted leaf, promises a short cut to learning the special adaptations of a given cultivar.

These tests were made to identify differences among cultivars with respect to characteristics of rooted leaves, to see the effects of stress on such characteristics, and to judge the suitability of rooted leaves for measuring storage root production potential as well as stress tolerance.

${ }^{1}$ Manuscript submitted to Editorial Board August 23, 1983.

${ }^{2}$ Research Horticulturist, Tropical Agriculture Research Station, Southern Region, Agricultural Research Service, U.S. Department of Agriculture, Mayagüez, Puerto Rico 00709 .

${ }^{3}$ Isbell, C. L., 1931. Regeneration of leaf cuttings of Ipomoea batatas, Bot. Gaz. 91: 41125.

${ }^{4}$ Wilson, L. A., 1967. The use of rooted leaves and grafted plants for the study of carbohydrate metabolism of sweet potato (Ipomoea batatas L. Lam), Proc. Int. Symp. Trop. Root Crops 1: 46-55.

${ }^{5}$ Martin, F. W., 1982. Technique for rooting sweet potato leaves, HortSci. 17: 395-6. 


\section{MATERIALS AND METHODS}

Fifteen well characterized sweet potato cultivars or breeding lines from the temperate zone and tropics were grown in the field at Mayagüez, Puerto Rico, and served as a source of leaves. A standard technique was used to select and root leaves in pots. ${ }^{5}$ After rooting, three uniform healthy leaves were selected as single plant replicates for each subsequent treatment. The length of the leaves was measured, and the leaves were grown for 8 weeks in the following environments: full sunlight out of doors; $67 \%$ full sunlight in the greenhouse, and $20 \%$ sunlight under fiberglass on a greenhouse bench. In addition, pots were placed in trays kept wet with $2 \mathrm{~cm}$ water in $67 \%$ full light in a greenhouse.

TABLE 1.-Characteristics measured or rated of rooted sweet potato leaves

\begin{tabular}{|c|c|c|}
\hline Characteristic & $\begin{array}{l}\text { Method of } \\
\text { evaluation }\end{array}$ & Scale \\
\hline 1. Green color of leaf & Rated & $\begin{array}{l}1=\text { yellow, } 2=\text { normal green, } 3=\text { dark } \\
\text { green }\end{array}$ \\
\hline 2. Anthocyanin of leaf & Rated & $\begin{array}{l}0=\text { none (normal), } 1=\text { minimum, } 2= \\
\text { some, } 3=\text { strong anthocyanin coloring }\end{array}$ \\
\hline 3. Leaf enlargement & Measured & Percent elongation \\
\hline 4. Petiole enlargement & $\begin{array}{l}\text { Measured, or } \\
\text { weighed }\end{array}$ & Maximum diameter of petiole, Grams \\
\hline $\begin{array}{l}\text { 5. Lenticel formation of } \\
\text { petiole }\end{array}$ & Rated & $\begin{array}{l}0=\text { none (normal) }, 1=\text { minimum, } 2= \\
\text { some, } 3=\text { many lenticels }\end{array}$ \\
\hline $\begin{array}{l}\text { 6. Size of fibrous root } \\
\text { systems }\end{array}$ & $\begin{array}{l}\text { Rated, or } \\
\text { weighed }\end{array}$ & $1=$ minimum,$-9=$ maximum Grams \\
\hline 7. Storage root & Weighed & Grams \\
\hline 8. Sprouting tendency & Rated & $\begin{array}{l}0=\text { none },-5=\text { sprouts emerging from } \\
\text { soil }\end{array}$ \\
\hline 9. Shade resistance & Calculated & $\begin{array}{l}\text { Storage root wt. in shade/storage root wt. } \\
\text { greenhouse }\end{array}$ \\
\hline 10. Flood resistance & Calculated & $\begin{array}{l}\text { Storage root wt. in water/storage root wt. } \\
\text { greenhouse }\end{array}$ \\
\hline 11. Full sunlight resistance & Calculated & $\begin{array}{l}\text { Storage root wt. in full sun/storage root } \\
\text { wt., greenhouse }\end{array}$ \\
\hline
\end{tabular}

After 8 weeks 11 characteristics including growth phenomena of rooted leaves as well as reactions to physiological stress situations were observed, estimated, or measured (table 1). Normal leaf color is green. If color is lost, leaves are yellowish, and if color is gained they are dark green. Under nutritional stress anthocyanin may develop in the leaves. Leaf enlargement was measured as percent increase in leaf length. Petiole enlargement was measured in terms of diameter at the widest point and in a second experiment, in terms of weight of petiole. Prominent lenticels may form on petioles and storage roots, and their number is easily 
estimated. The amount of fibrous roots was judged on an entirely subjective basis in the first experiment, and by weight in the second. Storage roots were detached from fibrous roots and weighed. Sprouting tendency was judged in terms of the relative frequency and degree of development of sprouts. For comparison, growth in the greenhouse was considered normal because rooted leaves in pots were stressed by direct sunlight out-of-doors. Shade resistance was calculated as the average storage root weight in $20 \%$ sunlight as compared to that in the greenhouse $(67 \%$ light). Flood resistance and full sunlight resistance were calculated in a similar fashion.

In a second experiment, leaves from five different cultivars were retested in three environments, $67 \%$ full sun, $20 \%$ full sun, and root flooding, as previously described. After 10 weeks, fibrous roots, storage roots, and petioles were weighed. Statistical analyses were made.

\section{RESULTS}

All rooted leaves pass through a growth process as follows: Week 1 , callousing of the cut petiole; week 2, initiation of the fibrous root system; week 3 , beginning of enlargement of the petiole and production of storage roots. During this time the leaf also enlarges in area. Although the leaves are normally green in color when cut and when rooted later in the greenhouse, rooted leaves lose their green color with time, and may develop a blush of anthocyanin. Leaves senesce in 8-12 weeks, and new sprouting can occur as early as 8 weeks after roots are initiated. If, however, a root from the pot enters the soil below, the leaf regreens rapidly, enlarges in size, and new shoots are soon formed. Thus, the normal growth pattern described here is that associated with response of a rooted leaf to a limited nutrient supply.

Under greenhouse conditions subtle differences can be seen in rooted leaves from different cultivars (table 2). Yellowing of the leaf is associated with cultivar and cannot be consistently related to other characteristics. Leaf enlargement appeared to depend on the initial size of the leaf, and was not consistent even within cultivars. Apparent differences were seen among cultivars in petiole enlargement, size of fibrous root system and weight of storage root. Rooted leaves of cultivars that yield heavily at Mayagüez ("White Jewel", "Gem", "Tai 57", "Centennial", "Jaspar") had enlarged petioles and large storage roots. The cultivars that yield poorly at Mayagüez ("Cubana", "Miguela", "Sulphur") have smaller petioles and smaller storage roots.

The greenhouse environment can be considered a standard, low stress environment even though sunlight was reduced to $67 \%$. The effects of environments of various degrees of additional stress changed the characteristics of the rooted leaves, and cultivar differences under these stress conditions were more obvious (table 3 ). 
TABLE 2.-Characteristics of rooted leaves from different sweet potato cultivars under greenhouse conditions 10 weeks after initiation

\begin{tabular}{|c|c|c|c|c|c|c|c|}
\hline Variety & $\begin{array}{l}\text { Greenleaf } \\
\text { color }^{1}\end{array}$ & $\begin{array}{l}\text { Anthocyanin } \\
\text { of leaf }^{1}\end{array}$ & $\begin{array}{c}\text { Leaf } \\
\text { enlargemnt }\end{array}$ & $\begin{array}{c}\text { Petiole } \\
\text { diameter }\end{array}$ & $\begin{array}{l}\text { Size of } \\
\text { fibrous } \\
\text { root } \\
\text { systems }^{1}\end{array}$ & $\begin{array}{l}\text { Weight of } \\
\text { storage } \\
\text { root }\end{array}$ & $\begin{array}{c}\text { Sprouting }{ }^{1} \\
\text { tendency }\end{array}$ \\
\hline & & & $\%$ & $\mathrm{~mm}$ & & $g$ & \\
\hline Jewel & 1.1 & 1 & 2 & 4.9 & 4.5 & 5.8 & 0 \\
\hline Tainan 57 & 2.0 & 1 & 16 & 5.1 & 4.0 & 8.5 & 0 \\
\hline Yellow Jersey & 1.2 & 0 & 4 & 8.0 & 3.2 & 4.0 & 1 \\
\hline Cubana & 2.2 & 0 & 2 & 4.8 & 3.5 & 1.8 & 0 \\
\hline Gem & 2.0 & 3 & 12 & 7.2 & 4.0 & 8.8 & 0 \\
\hline Miguela & 2.0 & 0 & 1 & 4.5 & 2.5 & 0.2 & 0 \\
\hline NC 718 & 2.8 & 3 & 25 & 4.8 & 3.8 & 3.1 & 0 \\
\hline Jasper & 1.8 & 0 & 10 & 7.6 & 2.8 & 8.5 & 1 \\
\hline W 149 & 2.0 & 0 & 6 & 8.5 & 2.8 & 2.2 & 1 \\
\hline Centennial & 1.5 & 2 & 3 & 7.8 & 4.0 & 8.8 & 1 \\
\hline Pelican & 1.8 & 0 & 15 & 5.2 & 4.2 & 5.0 & 0 \\
\hline Sulphur & 1.0 & 0 & 13 & 3.5 & 3.0 & 1.5 & 1 \\
\hline Dominica & 1.5 & 1 & 6 & 5.0 & 3.5 & 6.2 & 0 \\
\hline White Jewel & 2.5 & 1 & 35 & 5.4 & 4.2 & 10.5 & 0 \\
\hline NC 825 & 1.8 & 0 & 23 & 6.5 & 4.8 & 5.2 & 1 \\
\hline
\end{tabular}

${ }^{1}$ See table 1 for rating system. 
TABLE 3.-Modifications of rooted leaves due to stress conditions

\begin{tabular}{|c|c|c|c|c|c|c|c|c|c|}
\hline \multirow[b]{2}{*}{ Cultivar } & \multicolumn{3}{|c|}{ Full sunlight } & \multicolumn{3}{|c|}{ Shade } & \multicolumn{3}{|c|}{ Flooded roots } \\
\hline & $\begin{array}{l}\text { Antho- } \\
\text { cyanin } \\
\text { of leaves }{ }^{1}\end{array}$ & $\begin{array}{l}\text { Weight } \\
\text { storage } \\
\text { roots }\end{array}$ & $\begin{array}{l}\text { Percent } \\
\text { compared to } \\
\text { greenhouse }\end{array}$ & $\begin{array}{l}\text { Green } \\
\text { color of } \\
\text { leaves }\end{array}$ & $\begin{array}{l}\text { Weight of } \\
\text { storage } \\
\text { roots }\end{array}$ & $\begin{array}{l}\text { Percent } \\
\text { compared to } \\
\text { greenhouse }\end{array}$ & $\begin{array}{l}\text { Lenticel } \\
\text { produc- } \\
\text { tion }\end{array}$ & $\begin{array}{c}\text { Weight of } \\
\text { storage } \\
\text { roots }\end{array}$ & $\begin{array}{c}\text { Percent } \\
\text { compared to } \\
\text { greenhouse }\end{array}$ \\
\hline Jewel & 1 & 2.5 & 43 & 3.0 & 1.6 & 28 & 3 & 1.5 & 26 \\
\hline Tainan 57 & 2 & 3.8 & 45 & 3.0 & 0.6 & 7 & 0 & 0 & 0 \\
\hline Yellow Jersey & 0 & 2.6 & 65 & 3.0 & 0.0 & 0 & 3 & 0.0 & 0 \\
\hline Miguela & 1 & 0.2 & 100 & 3.0 & 0.0 & 0 & 1 & 0.0 & 0 \\
\hline NC 718 & 3 & 3.1 & 97 & 3.0 & 1.0 & 31 & 1 & 3.5 & 109 \\
\hline Jaspar & 1 & 6.2 & 73 & 3.0 & 2.7 & 32 & 0 & 0.0 & 0 \\
\hline W 149 & 1 & 1.8 & 82 & 3.0 & 0.9 & 41 & 2 & 0.0 & 0 \\
\hline Centennial & 3 & 2.8 & 32 & 3.0 & 0.1 & 2 & 3 & 0.5 & 6 \\
\hline Pelican Processor & 1 & 3.4 & 68 & 3.0 & 0.0 & 0 & 2 & 0.0 & 0 \\
\hline
\end{tabular}

${ }^{1}$ See table 1 for rating system. 
Full sunlight out-of-doors resulted in increased yellowing and anthocyanin coloration of the leaves. Storage root yields were reduced in all cultivars. However, the reductions were not pronounced.

Heavy shade was associated with healthy-looking dark green leaves. However, production of storage roots was reduced by 59 to $100 \%$ and strong cultivar differences were observed. Cultivars that yielded best in heavy shade were varieties that yielded well in the greenhouse except in the case of "White Jewel", whose yield was reduced $93 \%$ by heavy shade.

In the trials of rooted leaves with flooded roots the soil was constantly saturated with water. No storage roots were produced by 9 of the 15 cultivars. Six cultivars produced roots of only 6 to $10 \%$ of the weight of roots produced in the standard environment. The cultivar with largest storage roots, Gem, was also the cultivar with largest roots in heavy shade and full sun.

Flooding roots caused the development of prominent lenticels in the case of some cultivars. These lenticels resembled small darkened lumps 1-2 $\mathrm{mm}$ long. They appeared on the portion of the petiole covered with sand, and on tuberous roots, but not on the fibrous roots. The presence of lenticels apparently was unrelated to the production of storage roots.

Under all environments, the vigorous cultivar Gem produced more storage roots that any other cultivar. This cultivar also produced prominent lenticels on storage roots and petioles when roots were flooded. Petioles were larger and heavier than those of other varieties under all conditions. The breeding line NC 718 produced larger storage roots under flooding. The cultivar "White Jewel" produced poorly under stress, while the excellent Puerto Rican cultivar "Mina" performed poorly under all conditions.

Five cultivars showing difference in reaction to stress, when retested, showed the same relative differences (table 4). Shade reduced the weight of the storage root and of the tuberized petiole as well, but did not affect the weight of fibrous roots. Significant cultivar differences were seen in storage root and tuberized petiole. Flooding also decreased storage root and tuberous petiole weight, and tended to increase fibrous root weight. Again, cultivar differences were seen. The widely adapted cultivar "Gem" produced better under conditions of flooding than of shading. The wet soil-resistant cultivar "Jaspar" tuberized fairly well under shade as well as under flooding. The poorly adapted but occasionally high yielding cultivar "Sulphur" did not tuberize under stress conditions.

\section{DISCUSSION}

In the present study we used 15 cultivars of sweet potato that represent some of the best germplasm available in Puerto Rico. In a standard nonstress environment, only minor differences could be seen among 
TABLE 4.-Difference among 5 distinctive sweet potato cultivars with respect to tuberization of rooted leaves in three environments

\begin{tabular}{|c|c|c|c|c|c|c|c|c|c|}
\hline \multirow[b]{2}{*}{ Cultivar } & \multicolumn{3}{|c|}{ Low stress (67\% sun) } & \multicolumn{3}{|c|}{ Shade stress } & \multicolumn{3}{|c|}{ Flood stress } \\
\hline & $\begin{array}{l}\text { Fibrous } \\
\text { roots }\end{array}$ & $\begin{array}{l}\text { Tuberous } \\
\text { roots }\end{array}$ & Petiole & $\begin{array}{c}\text { Fibrous } \\
\text { roots }\end{array}$ & $\begin{array}{l}\text { Tuberous } \\
\text { roots }\end{array}$ & Petiole & $\begin{array}{l}\text { Fibrous } \\
\text { roots }\end{array}$ & $\begin{array}{c}\text { Tuberous } \\
\text { roots }\end{array}$ & Petiole \\
\hline & $\mathrm{g}$ & $g$ & $\mathrm{~g}$ & $\mathrm{~g}$ & $\mathrm{~g}$ & $\mathrm{~g}$ & $\mathrm{~g}$ & $\mathrm{~g}$ & g \\
\hline Gem & $3.3 \mathrm{a}^{1}$ & $9.3 \mathrm{ab}$ & $4.1 \mathrm{a}$ & $4.2 \mathrm{a}$ & $1.1 \mathrm{~b}$ & $2.3 \mathrm{ab}$ & $5.4 \mathrm{a}$ & $3.2 \mathrm{a}$ & $4.4 \mathrm{a}$ \\
\hline Jaspar & $3.0 \mathrm{a}$ & $10.3 \mathrm{a}$ & $3.8 \mathrm{a}$ & $3.3 \mathrm{a}$ & $3.2 \mathrm{a}$ & $3.4 \mathrm{a}$ & $3.6 \mathrm{a}$ & $5.0 \mathrm{a}$ & $3.2 a b$ \\
\hline Miguela & $3.6 \mathrm{a}$ & $1.0 \mathrm{c}$ & $1.5 \mathrm{~b}$ & $3.6 \mathrm{a}$ & $0.06 \mathrm{~b}$ & $1.3 \mathrm{~b}$ & $2.9 \mathrm{a}$ & $0.0 \mathrm{~b}$ & $1.2 \mathrm{~b}$ \\
\hline Cubana & $3.5 a$ & $1.8 \mathrm{c}$ & $1.6 \mathrm{~b}$ & $3.5 a$ & $0.2 \mathrm{~b}$ & $1.1 \mathrm{~b}$ & $5.1 \mathrm{a}$ & $0.0 \mathrm{~b}$ & $1.1 \mathrm{~b}$ \\
\hline Sulphur & $3.2 \mathrm{a}$ & $7.5 \mathrm{~b}$ & $2.2 \mathrm{~b}$ & $3.8 \mathrm{a}$ & $0.0 \mathrm{~b}$ & $1.1 \mathrm{~b}$ & $4.3 \mathrm{a}$ & $0.0 \mathrm{~b}$ & $1.4 \mathrm{~b}$ \\
\hline
\end{tabular}

${ }^{1}$ Means followed by the same letter do not differ significantly at $(\mathrm{p}=0.05)$. 
leaves except for differences in ability to produce storage roots. In environments that stressed the plants, however, wider differences became apparent. In addition, new or more extreme variation occurred which may be indicative of adaptation.

In full sun, stress to potted leaf cuttings includes drought and heating of the pots. Rooted leaves grow less well and produce smaller storage roots under full sun than in the protected environment of the greenhouse. Growth rapidly uses up the nutrients from the leaf, and leaves turn yellow or sometimes red with anthocyanin.

In heavy shade there is a compensatory mechanism, increased green color, which gives the impression of healthy growth. Nevertheless, shade strongly reduces storage root production.

In the case of flooded roots, abnormal lenticels are often formed on below ground parts which might increase air uptake. Storage root production is drastically reduced, but fibrous roots and petioles may increase in weight.

It is noteworthy that in all environments tested, one cultivar, "Gem", was outstanding. This cultivar has proved to be the most dependable and high yielding cultivar in Puerto Rico ${ }^{6}$. Other high yielding varieties also tolerated some stress conditions. Thus, it appears from these limited observations that generalized adaptation in sweet potato is closely related to stress resistance. Moreover, cultivars that are known to be poor yielding or poorly adapted responded even more poorly to stress environments.

These deductions were drawn from relatively small and inexpensive experiments in the laboratory with rooted leaves. Although much remains to be done to verify this assertion, it appears that rooted leaves are versatile tools for measuring stress resistance in small areas in short periods of time.

\section{RESUMEN}

Hojas enraizadas de 15 variedades de batata se cultivaron en tiestos pequeños en cuatro ambientes, de los cuales tres se consideraron que no eran apropiados: invernadero, a pleno sol, sombra parcial e inundación de las raíces. Los efectos de estos tres ambientes se midieron con respecto a ocho características. Cada uno redujo la producción de raíces tuberculizadas y produjo reacciones características. Las variedades mostraron diferencias en su reacción a los diversos ambientes. Algunas cultivares, especialmente "Gem" y "Jaspar", fueron más productivas y menos afectadas por el ambiente que las otras.

${ }^{6}$ Badillo-Feliciano, J., Morales-Muñoz, A. and Sierra, C., 1976. Performance of yellowfleshed sweetpotato cultivars at two locations in Puerto Rico, J. Agric. Univ. P.R. 60: 15462. 